Снежана В. Божић ${ }^{1}$

Универзитет у Нишу

Филозофски факултет

Департман за србистику
Оригинални научни рад УДК 821.163.41.09-93 Ђурђев Д. П.

Примљен: 31. 3. 2020.

\title{
УТИЦАЈ ИНТЕРТЕКСТУАЛНОСТИ И ИГРИВОСТИ НА КОМУНИКАТИВНОСТ ПОЕЗИЈЕ ЗА ДЕЦУ И МЛАДЕ ПОПА Д. ЂУРЪЕВА
}

У раду се испитује утицај интертекстуалности као битног обележја стваралаштва Попа Д. Ђурђева на ниво комуникативности његове поезије, с посебним фокусом на публику којој је та поезија примарно намењена - децу и младе. У вези с тим разматрају се два главна питања: уноси ли интертекстуалност аспект игривости у текст и до којих нивоа „заиграног” текста дете-читалац у чину рецепције заправо допире. У настојању да се на наведена питања одговори, анализирана су два књижевна остварења Попа Ђурђева - збирка Блудилник (1988) и поема Мрњавчевићи (2016).

Кључне речи: интертекстуалност, игривост, поезија за децу, дете-читалац, читалачке компетенције

Интертекстуалност, категорија која, на неки начин, представља опште место савремене књижевности, па и књижевности за децу, увек је подстицајан аспект истраживања и тумачења књижевног дела, а ако представља његову већ при првом читању јасно уочљиву особину - утолико пре. Најопштијим дефиницијама интертекстуалност се одређује као директно упућивање/позивање на неки други (књижевни) текст или препознавање одређених сличних или истих тема у различитим текстовима; исти појам користи се да означи различите односе међу текстовима, испреплетаност и прожимање њихових значења. На који начин интертекстуалност чини дело комуникативнијим у чину рецепције и каквог читаоца би таква „појачана”, односно другим текстовима оснажена комуникација захтевала, једно је од питања које нас посебно занима, имајући у виду публику којој се књижевност за децу обраћа (дакле, пре свега децу и младе, али и друге категорије читалаца) ${ }^{2}$.

\footnotetext{
${ }^{1}$ snezana.bozic@filfak.ni.ac.rs

${ }^{2}$ Не улазимо у разматрање питања намене које је у темељу конституисања књижевности за децу/дечје књижевности као посебног вида књижевности (видети о томе нпр.
} 
У истом смислу занима нас и игривост/игровност. Као феномен који долази из дечијег света, она је нешто што се, у различитим варијантама, подразумева када говоримо о књижевности, односно о поезији за децу. Игру не може да не разуме онај ко се и сам непрестано игра. ${ }^{3}$ Међутим, да ли се у свим играма подједнако ужива; у којој мери то треба да буде лична (дететова) игра, да би у њој радо учествовало? Нуди ли књижевност/поезија за децу баш такву игру - ону у коју би да се одмах укључиш или је игра таква да би радије гледао са стране док се други играју?

Потом, ако повежемо ове две категорије запитаности долазимо до наредне: може ли се интертекстуалност у контексту књижевности (за децу) посматрати као игра ${ }^{4}$, тј. уноси ли интертекстуалност аспект игривости у текст? Потврдан одговор на ово питање води нас, даље, до запажања да је таква игра најмање трострука - игра текста с другим текстовима и игра стваралачког духа, али и игра одгонетања и продубљивања значења у чину читања, односно, у мета-читању, игра испитивања граница рецепцијских могућности читалаца.

Значењска носивост појма игре, начини на које се о њој може размишљати, додатно усложњавају одговоре на ова питања. Како игра у језику и игра у мишљењу бивају део праве дечије игре? Бивају ли уопште? До којих нивоа/дубина заиграног текста дете-читалац заправо допире?

Из свих наведених питања јасно да нас поезија за децу, па у тим оквирима и поезија Попа Д. Ђурђева, интересује управо посматрана из угла детета/младог човека-читаоца кога склоност ка игри (игривост) примарно обележава. Дакле, интересује нас дете које ову поезију чита и начин на који оно то чини.

Слична питања покренута су, недавно, у знатно ширем и превасходно теоријском контексту. Бавећи се анализом различитих аспеката „пријема књижевног текста који су садржани у инстанцама имплищитнног

VUKOVIĆ 1996: 18-28), али нам је, за разматрања у овом раду, важно одређење да се „и k. z. d. ubrajaju dela koja pisci stvaraju vodeći računa o mladim čitaocima - o moći njihove percepcije" (RKT 1992: 377). Не треба, међутим, занемарити још један аспект, који се тиче критичког вредновања књижевности/поезије за децу: „Добра песма за децу мора занимати и одраслог читаоца. Она мора садржавати обрт или значење које може обрадовати и већег читаоца него што је дете. Она мора имати још једну вертикалну димензију и значити нешто друго сем онога што је деци речено" (RADOVIĆ 2006: 418).

${ }^{3} \mathrm{C}$ друге стране, ,pisac mora imati sposobnost uživljavanja u dječji aspekt gledanja na svijet, pa je, [...], 'literatura za djecu neka vrsta umjetnog obrta, zasnovana na autorovoj sposobnosti da se psihološki uživljava, ili tzv. 'naivna umjetnost' koja se hrani iz infantilnog reziduma u ličnosti odraslog pisca" (Kramberger, према VUKOVIĆ 1996: 23).

${ }^{4}$ Овакво размишљање је на линији схватања да „kao delatnost fantazije, igra ima duhovni karakter, pa se umetnost i s njom povezana estetska prijatnost može shvatiti i kao 'igračka' aktivnost" (RKT, 278). У том смислу, интертекстуалност би била само врста стваралачке игровне активности, врста игре. 
читаоия (V. Iser), наратера (G. Prince), наративне публике (J. Phelan, P. Rabinowitz)", теоретичарка књижевности C. Милосављевић Милић указује на то да „,[у]смереност лирског или епског наратива ка детету као 'идеалном реципијенту' имплицитно отвара питање (не)усаглашености између реторичких и интерпретативних стратегија, па се може говорити о различитом степену разилажења између имплицитног читаоца и наративне публике”, закључујући да „ова дистинкција може представљати и базично полазиште за ревизију методолошко-интерпретативних аспеката књижевности за децу". 5 Овакви ставови на одређени начин потврђују смисленост наших настојања да у фокус истраживачке пажње поставимо управо дете-читаоца, и то у односу на комуникативне потенцијале текста и способност младог читаоца да те потенцијале актуализује и освести (имајући у виду суштински интерактивну природу читања).

У низу питања која претендују да одговорима досегну макар делић сазнања о обележјима поезије за децу и њене рецепције, не можемо а да не поставимо и једно прагматично. Тиче се аспекта који је својеврстан предуслов чина рецепције. Наиме, како остварења књижевности за децу проналазе пут до оних којима су намењена? Да ли је, кад говоримо о комуникативности, директна, непосредна комуникација аутора са читаоцима (уприличени сусрети) добар начин? Шта се њоме добија, а шта губи? Како год да на ова питања одговоримо, евидентно је и то начин коме се у новије време често прибегава, па се може посматрати као битно обележје социо-културне позиције књижевности за децу данас. Иако утисак да с публиком, ипак, боље комуницира (и да је више читана) поезија чији су аутори спремни на директне контакте са својим читаоцима (свих категорија) не мора да буде тачан, чини се да је овај, наизглед ирелевантан аспект, заправо битан када је књижевност за децу у питању. Остаје да се прати и истражује, али треба рећи да се и овај моменат узима у обзир у неким студијама које настоје да утврде и опишу типолошке моделе савремене српске поезије за децу. Тако се, на пример, скреће пажња на чињеницу да миметички тип поезије за децу представља поезију која је данас „веома популарна, њени песници су често окренути естради и непосредном контакту с публиком" (LJUŠTANOVIĆ 2018: 72, истакла C. Б.); поред предности указује се и на неке негативне стране ове појаве - наиме, поједини песници често подилазе укусу публике тако да „у ову поезију продире и претерана сентименталност и различити видови тривијалности" (ISTO).

У вези са функционалним, прагматичним питањима, не треба заборавити наставнике и учитеље као посреднике између књижевног текста (понекад и његовог аутора) и ученика (детета-читаоца). Какви су настав-

${ }^{5}$ Излагање Мултипликација фигуре читаоца у књижевности за децу (Јагодина, 2017). 
ници читаоци књижевности/поезије за децу и које видове комуникације они са њом остварују? На који начин њихове методичке концепције и стручни приступи текстовима књижевности за децу доприносе оспособљавању ученика-читаоца да препознаје и тумачи интертекстуалне везе и друге особине карактеристичне за ову врсту књижевности, какве су: „укључивање читаоца у игру и имагинацију, при чему и језик постаје играчка духа' (игре звучањем, значењем, морфолошким облицима речи, креирање неологизама, укључивање непесничке лексике у певање), онеобичавање, примена парадокса, гротеске и нонсенса, измењен, инвертован или пародијски однос према поучном, као и наглашена интертекстуалност, метатекстуалност и цитатност [...], потом заснованост на продуктивном односу према усменој традицији” (ОРАС̆ІС́ 2018: 4).

Управо у последњем низу питања видимо могућност да се размишљања о интертекстуалности и игривости као „појачивачима” комуникативности поезије Попа Ђурђева (која, иначе, поседује готово све претходно наведене особине својствене књижевности за децу), повежу са методиком наставе књижевности, што је такође аспект који нас занима. У том смислу, прихватљиво методичко-методолошко упориште за приступ изабраним Ђурђевљевим поетским текстовима долази из области афективне наратологије, управо преко везе која се успоставља између одређених постулата савремене методике наставе и актуелних теоријско-методолошких увида у поменутој области проучавања књижевности. ${ }^{6}$ У ово се могу укључити и нека новија разматрања о адресату (лирском објекту) у поезији, јер се тичу прималаца лирског текста ${ }^{7}$, што (како је у уводу указано) није без значаја када говоримо о поезији за децу, односно о поезији Ђурђева.

Овде се заустављамо у утврђивању ширег контекста и опсега тема које нас занимају, да бисмо се осврнули на два књижевна остварења Попа

\footnotetext{
${ }^{6}$ Овде мислимо, пре свега, на „савез срца и ума” - метафоричну конструкцију којом познати хрватски методичар наставе Драгутин Росандић упућује на однос доживљајног и сазнајног елемента у прихватању „Књижевне уметнине”, али и на ток, односно редослед комуникације ученика и књижевноуметничког текста. Дакле, полазиште је доживљај дела, његова емоционална спознаја која у себи садржи елементе естетског уживања, узбуђења и мисаоне узнемирености (видети: ROSANDIĆ 1986: 208). Веза овог методичког постулата са афективном наратологијом (теорије Патрика К. Хогана / Patrick C. Hogan/, Кита Оутлија /Keith Oatley/, Сузан Кин /Suzzane Keen/ и др.) остварује се преко разматрања удела емоција, емпатије, емпатијског узнемирења и др. у наставној рецепцији књижевног дела, односно увођењем емпатијско-етичког модела читања у наставу књижевности. Видети о томе: (BOŽIĆ 2020).

${ }^{7}$ У раду о адресату у лирској поезији указује се на четири ентитета примаоца, а то су: реалан/емпиријски читалац, имплицитни читалац (тј. публика имплицитног аутора), лирски објекат (публика лирског субјекта) и лирски лик у функцији лирског објекта. Видети: (JOVANOVIĆ 2017).
} 
Ђурђева узета за анализу. Једно је Блудилник, поетска збирка објављена 1988. године, а друго поема Мрњавчевићи из 2016. године. Много времена и објављених књига стало је између, али ова два 'краја' 8 тако описаног лука омогућавају нам да, бар делимично, сагледамо Ђурђевљев стваралачки пут и уочимо битне и особине и промене које је донело време, животно сазревање и поетичко (само)профилисање.

У поезији Попа Ђурђева, која као доминантан први утисак оставља одбљесак интелигенције и интелектуалости, бриткости ума, препознајемо елементе свих типова трипартитне Љуштановићеве типологије савременог српског песништва. ${ }^{9}$ Приметан је, код овог песника, ход од поезије у којој доминира миметичко и сублимно-лирско до наглашено игровне - у новијим песмама које се гледају, одгонетају, колажирају, у којима се полази од онога што је спољашње и представља визуелни ефекат, ка унутрашњем, мишљеном, ма где да се за дете-читаоца тај пут завршава ${ }^{10}$. Има остварења у којима та игра, пак, остаје доминантно интертекстуална, игра духа, језика и читалачког искуства, тј. игра духа у језику, као у поеми Мрњавчевићи.

Иако нам је, у контексту свих на почетку постављених питања, песнички узорак за сагледавање стваралаштва Попа Ђуђева прилично ограничен (па остаје као место за додатна истраживања), ипак можемо да изнесемо и одређена конкретнија запажања.

Песничка збирка Блудилник у поднаслову је одређена као поетски практикум за усмерењаке. У време када је објављена, касних осамдесетих година 20. века, она је њиме могла добро комуницирати са публиком ${ }^{11}$ којој је (била) намењена. Претпостављамо да би и данашњем младом читаоцу било познато значење речи „практикум”, док би појам „усмерењаци” тражио додатно појашњење и контекстуализацију (,усмерењак” је ученик усмереног образовања у једној од реформи образовног система у земљи). Дакле, узраст читаоца коме је збирка намењена је 14 до 18 година, време када, бар према неким истраживањима, њега и занима оно што о интимним и другим питањима која га окупирају могу, у књижев-

\footnotetext{
${ }^{8}$ Условно речено краја, мислимо само на наше читање у овом раду.

${ }^{9}$ Поред миметичког, који је овде већ поменут, ту су и сублимно-лирски и игровни модел (LJUŠTANOVIĆ 2018).

${ }^{10}$ Сличну запитаност исказује и Љуштановић (бавећи се, додуше Ђурђевљевом збирком Слик ковница): „Остаје отворено питање, у којој мери песме и сличице Попа Д. Ђурђева, без обзира на то што су битно одређене и дечјом игром, због своје сложене везе с културом уопште, долазе до савременог детета, колико чекају неко будуће време - 'Кад дорасту, кад размисле, / Каз'ће им се само!” (LJUŠTANOVIĆ 2019: 41).

11 Овде је израз публика употребљен у значењу које у виду има реалне/емпиријске читаоце.
} 
ности, да му кажу романи и - поезија ${ }^{12}$. У испитивање начина на који с таквим читаоцем комуницира ова збирка полазимо од наслова, речи „блудилник” - кованице настале у поигравању речима будилник и блуд. Јасна је семантичко-смисаона веза која се успоставља између наслова и садржине песама у збирци: постоји доба у животу када се тело буди (огласи се неки природни будилник у њему) и оно постаје отворено (жељно) чулних искустава. Притом, реч „блуд” уноси и наговештај забрањеног, порочног, неморалног... Сугестија таквог буђења, која долази од наслова као паратекстуалног елемента, може да пробуди и интересовање младог читаоца; наиме, у поменутом периоду одрастања и сазревања поједини сегменти живота који младу особу окупирају (у мисаоно-емотивном погледу) углавном су недоступни, а често делују и фрустрирајуће. Зато и „практикум” из поднаслова обећава - да ће књига, тј. приручник понудити неко конкретно упутство (макар и поетско) за стицање одређене вештине, оне за којом је жеља пробуђена. У најширем смислу, то би могла да буде жеља за животом, потреба да се он искуси и сазна.

Збрика се састоји од четири циклуса.

Слично начину на који је древни човек стварајући митове себи тумачио свет који га окружује, а далек му је, застрашујући и неподложан његовој вољи, Поп Ђурђев у првом циклусу, ЗвЕздАНИ моЛЕРАЈИ, креира једну мини-космогонију, приписујући небеским телима и појавама особине и ситуације препознатљиве из свакодневног људског живота. То ‘бојење звезда' сопственим бојама начин је да се нешто што је далеко приближи, да се небеско смести у земаљске и људске оквире. Притом, лепота недостижног није унижена, него је, баш таквим уоквиравањима, додатно наглашена. Сваки покушај поређења суштински неупоредивог производи ефекат очуђавања и скреће пажњу на поредбене корелате: стављени у исту раван они бивају лако сагледани у својим, условно речено „реалним” (емпиријским, искуственим) димензијама - небо, земља и човек (односно звезде, облаци, дуга, ноћ, дан, временске непогоде...). Наводимо само један пример, песму „Незванични првак света”: Вест из Олимпијског комитета: / Небо је незванични првак света, / оно може у вис да скочи / колико досежу очи, / зато некрунисаном атлетском краљу / додељујемо златну сунчеву медаљу (ĐURĐEV 1988: 19).

\footnotetext{
${ }^{12}$ „U mladih ljudi od 15 do 18 godina povećano je interesovanje za vlastiti unutrašnji svet, pojačava se interesovanje za spoznavanje vlastite ličnosti, nastupa proces samovaspitanja. Knjiga se u tom dobu ne pojavljuje samo kao izvor za upoznavanje sveta nego, pre svega, za upoznavanje samoga sebe. Baš time se objašnjava posebno interesovanje učenika srednje škole za dela o mladosti.” (Badrova, Sigal, према ROSANDIĆ 1986: 475). Слично: „Od 15. do 20. godine prema istraživanjima Bühler - Engelmann razdoblje je lirike i romana što je povezano $s$ refleksijom o unutrašnjem životu, razmišljanjima o svijetu, smislu života u toj dobi " (KUVAČ LEVAČIĆ 2013: 17).
} 
Лирски субјекат у хомодијегетичкој позицији (који проговара из колективног ми, указујући тиме на сопствену припадност интерпретативној заједници којој се обраћа - „додељујемо”) стоји наспрам неба, које представља хомодијегетички лирски објекат (што је сугерисано и насловом песме), и упоредо са лирским објектом који је мета (онај коме је, заправо, порука упућена, Premindžer 2003, према JOVANOVIĆ 2017: 205). У комуникативном смислу, важна је дистинкција између ове две врсте лирских објеката који се у песми појављују и однос који се успоставља између њих и лирског субјекта. С обзиром на то да се ни имплицитни и емпиријски читалац не могу идентификовати са „овако силним лирским објектом” (JOVANOVIĆ 2017: 204) какав је небо, можемо закључити да је лирски објекат који је мета близак имплицитном читаоцу, као и да се интензивнија идентификација емпиријског читаоца успоставља са лирским субјектом. Игра додељивања медаље небу је колективна, у њој су лирски субјекат и читалац суиграчи (што је и наглашено употребљеним првим лицем множине глагола додељивати).

Други циклус, Блудилник, наговештен је последњом песмом прве целине „Још сањива природа се буди”, чиме се успоставља добра повезаност делова збирке. У овој целини, која са главним насловом кореспондира до те мере да га преузима (или обрнуто), доминантни су мотиви љубави, у различитим варијантама (заљубљивање, љубавно писмо, пољупци, чулност и страст), а поред тематско-мотивске комуникативности, веза са читаоцем оснажује се елементима шале, хумора, луцидне досетљивости, наговештајима ласцивности, али и алузијама које су више од наговештаја (видети, на пример, завршни стих последње строфе ${ }^{13}$ у песми „Сена долази у Јагодину", ĐURĐEV 1988: 31).

Песме овог циклуса одлично дочаравају несклад жеља и реалности „пробуђене” младе особе: она стреми љубави (и чулној) и види је у свему око себе (цео свет је у загрљају, у љубљењу, страсти ${ }^{14}$ ), али још увек јој

\footnotetext{
${ }^{13}$ „И опет је водим на Мораву / да гледамо Месечеву мену, / па је зовнем иза једног пласта / јер је Жанет навикла на СЕНУ.” Игра речима Сена (река у Француској) и сено (осушена трава) има јасну сексуалну конотацију. У том чину који се одвија на сену (далеко од Сене, у Јагодини), описаном у последњем стиху, скривена је, на одређени начин, и поента песме. Жанета (лирски објекат) заборавља на Париз, јер и Балкан има своје дражи „кад проникнеш у његове тајне"; нека врста интимне љубавне исповести хомодијегетичког лирског субјекта омогућава успостављање блискости са читаоцем до степена који доводи до потпуног укидања граница у комуникацији и поентирања оним што можда не би морало да се каже (последњи стих песме). Тиме је, с друге стране, хоризонт очекивања постављен насловом збирке оправдан и испуњен, а песник је остао доследан свом ставу да „писац не може бити пуританац, пун предрасуда” и да нема ничег лошег у томе што је „погдегде о љубави говорио мало слободније”, јер деца то очекују; „њима треба књига уз коју ће се мање осећати децом" (ĐURĐEV 1988: 71).

${ }^{14}$ О томе певају песме „Дијалог у природи”, „Природа се љуби”, „Блудилник”.
} 
се само стидљиво и усплахирено приближава, најреалније у сновима и маштањима. Ту свеопшту љубавну разиграност природе лирски субјекат прати помно и узбуђено, из ње се преузимају (свесно и несвесно, нагонски) модели понашања: „а ми, / на пропланку више задњих кућа, / све гледамо шта ће даље бити, / и кад клоне Сунце до сванућа, / шта ће нам се у сну догодити” (ĐURĐEV 1988: 27). Притом, ово „ми” лирског субјекта може бити хомодијегетички „удвојени” глас заљубљеног пара или колективно ми дружине вршњака/вршњакиња, у сваком случају, глас који у раван песничког наратива уводи младе читаоце спремне да се са њим поистовете.

Носећа песма циклуса свакако је „Блудилник” - објава опште законитости која влада светом, објашњење односа флоре и фауне, уз ненаметљиву дидактичку ноту којом се указује на лепоту природе и снагу неписаних закона који њоме владају. Њен дитирамбски тон, дужина стиха и ритмичност, као и значењски слој призивају, издалека, Ј. Ј. Змаја и песму „Ала је леп овај свет”.

Посебно се својом сликовитошћу и семантичком носивошћу у другом циклусу издваја песма „Облак над шљивиком”. Већ наслов сугерише љубавни заплет, асоцирајући, у још једном интертекстуалном поигравању, на познати наслов светске књижевности - „Облак у панталонама" Владимира Мајаковског. Међутим, насловом се та игра и окончава, и удаљена асоцијација већ након првог стиха губи на значају. Облак у Ђурђевљевој песми је само место љубавног чина Месеца и звезде ${ }^{15}$, али је у паралелизму који се успоставља на плану хронотопа и значења много важније збивање под облаком, на земљи, у шљивику. На трагу „звезданог молераја" из првог циклуса, Месец је мангуп који „звезду притишће” у љубавном облак-гнезду, док лирски субјекат у шљивику, у друштву „косе плаве“, посматра, замишљен и због нечега посрамљен, како се на небу реализује тај љубавни чин. Најзанимљивији ефекат постигнут је својеврсним замагљивањем разрешења датог у последњој строфи. Док је сасвим јасно шта се дешавало у облаку над шљивиком, збивање $y$ шљивику остаје отворено за различите рецепцијске конкретизације. Након љубавног чина, кад Месец побегне и сакрије се иза других облака, „међу своје отићи ће звезда / а по њеном врату освануће шљиве" (ĐURĐEV 1988: 30). Ко ће на свом врату понети „шљиве” (мале модрице од љубавних угриза), само звезда или и девојка (,плава коса”) која по растанку одлази својој кући (,међу своје”), препуштено је читаоцу да протумачи.

Преостала два циклуса, ВЕЛИкО ЗидНО оГЛЕДАЛО и ДУНАВ ПЕШАчи низводно - тематизују елементарна егзистенцијална питања (чула,

15 „Ноћ пуца ко брука, / Месец се мангупски небом клати / па звезду шчепа око струка / и у облак се са њом суноврати” (ĐURĐEV 1988: 30). 
жеље, живљење и пролазност, завичајност), а у низу песама остварена су духовита интертекстуална повезивања и за Попа Ђурђева карактеристично интегрисање елемената усмене традиције у савремени контекст. Песма „Кад млидијах умрети од Шекспира” доводи у везу Шекспировог Хамлета и епитаф на гробу Бранка Радичевића: „Неодлучни Хамлет/ као свако дете / ненавикнут да се / преко њега свете, // ту је таман нешто / учинити хтео/ али час умрли / њега је помео" (ĐURĐEV 1988: 49); песму „Бајка коју сте већ чули” чини један дистих: „Снежана је једна била / и с њом седам имбецила” (ĐURĐEV 1988: 50) ${ }^{16}$; наслов „Волите ли Змаја” део је интертекстуалног поигравања у песми која представља дијалог између човековог малог и великог мозга, испеваној на трагу Змајеве поетике певања за децу; „Сетна песма” призива „Фрулу” Момчила Настасијевића.

Насловна песма последњег циклуса „Дунав који пешачи низводно” поново у свести читаоца оживљава Бранка Радичевића и, овога пута, његов „Ђачки растанак”. Обележена инвокацијом и апострофом којима се зазива и у позицију лирског објекта доводи Дунав, ова поема може бити репрезентативан пример завичајног родољубља и рефлексивног певања; персонификованом Дунаву лирски субјекат обраћа се са: „мој чорбасти пријатељу”, „,тари мој”, „бриго јогунаста и текућа“, „силниче” и сл. Он је кицош, боем, бећар, „љубавник разводњених очију”, стога своје место може да пронађе у Блудилнику. Збирку затварају „Београдске разгледнице” - четвороделна поема, при чему је сваки део „разгледница” Београда из једног годишњег доба (започиње пролећем, завршава зимом). Препознатљива обележја града инкорпорирана су, сликовито и живописно, у развијене и заокружене песничке слике које подсећају на Вивалдијева „Четири годишња доба"; у духу Блудилника у највећој мери је, очекивано, пролећна разгледница: „Пролеће је зато да се воли, / кад оно дође, направи дар-мар / и сакрије се до идућег мандата / у неки зидни календар, / а дотле ће већ све да се преболи" (ĐURĐEV 1988: 62). Тематско уопштавање у последњем циклусу (град, годишња доба, природа) враћа читаоца на почетак збирке, „звезданим молерајима”. Тако се описује круг, односно уоквирава и суштински контекстуализује средишња тема - психофизичког и емоционалног буђења, сазревања, самосагледавања и самеравања себе са светом који се, пред младим бићем, тек отвара, у свој својој величини и непојамности.

С циљем да са читаоцима успостави што интензивнију комуникацију, аутор се у књизи оглашава и својеврсним поговором и биографском

16 Интертекстуална (и интермедијална) веза може се успоставити на ширем пољу популарне културе; наиме, у песми „Мама, тата” рок групе Кербер налази се стих „Снежана је једна била / а патуљака је шест...”. Песма се налази на албуму „Пета страна света” који је објављен 1990. године. 
белешком у првом лицу, што је такође оригиналан поступак који може позитивно утицати на степен комуникативности књиге у целини.

У поеми Мрњавчевићи (2016) опева се животна и љубавна судбина мачора Марка, чиме се у подтекст смешта епски лик Марка Краљевића и од самог наслова отвара занимљива и комплексна интертекстуална игра. Она, као свака игра, започиње објашњењем правила, која свим учесницима треба да буду јасна; наиме, аутор у почетној напомени „Да се разумемо..." свом младом читаоцу скреће пажњу да се пред њим не налази „историјска певанка о породици Мрњавчевић, која је била изразити представник српске средњовековне властеле, а чији је свима надалеко добро познат изданак био јунак над јунацима - Краљевић Марко”, већ да је „реч о породици мачака, прецизније - о домаћим мачкама, а како се оне оглашавају са мрњау, отуда и овај збирни назив за њих: Мрњавчевићи" (ĐURĐEV 2016). Ова напомена има не само информативну улогу него је и у функцији мотивисања за читање.

Поему отвара портрет црне мачке - страшне, пуначке и алаве. Њен изглед али и јеловник, ловачке и кулинарске вештине пресудне су за придобијање Марка, жутог мачора „пуштеног с ланца”, скитнице и боема, „шмекер[а] светског гласа” коме су досадиле све друге мачке (,шатиране и плавуше, / изблајхане, витког стаса") и жељан је да се скраси покрај црне маце и њене домаће кухиње.

Поема Мрњавчевићи представља изузетно захвално штиво за испитивање утицаја интертекстуалности и језичке и значењске игривости на рецепцију, тј. начин комуникације текста са читаоцем; засићеност дела интертекстуалним алузијама и цитатима из поезије Лазе Костића, усменог епског песништва, Јесењина и др. ${ }^{17}$, уз интерполацију фразеологизама и жаргонских израза, ствара специфичан језичко-стилски хибрид који рецепцију чини узбудљивом духовном игром, за читаоца који препознаје и разуме „места додира" 18 ; ономе ко тој игри није дорастао у помоћ прискачу духовите илустрације, омогућавајући читање и разумевање базичне приче (о љубавној вези мачке и мачора) и забаву у интелигентним повезивањима ниског и узвишеног, свакодневног и књижевног, у хумористичком тону и суштински ведрој атмосфери поеме.

Посебно су, у визуелном смислу, занимљиве поједине илустрације ${ }^{19}$ које такође „призивају” друге текстове, односно ауторе (најупечатљивији

\footnotetext{
${ }_{17}$ Детаљније о овоме видети (ОРАС̆І Í 2019: 16-21).

${ }^{18}$ Теорија рецепције одавно је осветлила чињеницу да „с̌italac može opažati djelo u užem horizontu svojih vlastitih književnih očekivanja (koja oblikuju sva iskustva književnosti s kojima se čitatelj dotada susreo i koja za njega predstavljaju književnu tradiciju) te i u širem horizontu svoga životnog iskustva" (KUVAČ LEVAČIĆ 2013: 14).

${ }^{19}$ Књигу је илустровао Коста Миловановић.
} 
пример свакако је склупчана мачка која дрема нацртана тако да асоцира на чувену илустрацију - цртеж Малог Принца који одрасли виде као шешир, в. ĐURĐEV 2016: 10). Та вишеструкост деловања (преко текста и слика) представља посебан квалитет поезије Попа Ђурђева. ${ }^{20}$

На отворено истраживачко питање о томе колико је дете-читалац вешто у игри откривања свих у текст и слику уписаних веза и у којој мери је рецепција ограничена ако он не успева да дешифрује сигнале које му текст шаље (тј. не препознаје постојеће линкове) можемо, чини се, дати бар делимично задовољавајући одговор. Попут жутог мачора из поеме, и млади читалац: „има(ш) сјајну перспективу /успе(ш) ли се само, к том, разбрати у плетиву, / међу јавом и мед сном" (ĐURĐEV 2016: 35). Богаћењем сопственог животног и читалачког искуства, млади читалац ће, у различитим периодима одрастања, при сваком поновљеном читању једног текста бити у могућности да открива његове нове слојеве, да уочава везе које раније није могао, али и да антиципира нека будућа искуства и сазнања (књижевна, културолошка, лична). Ово важи за читање било ког текста, а нарочито за текстове попут Ђурђевљевих, у које је уписано обиље референци, понуђених читаоцу да, у чину рецепције, њиховим уочавањем, повезивањем и тумачењем проширује и продубљује значења и смисао основног текста.

У том смислу није занемарљива ни улога наставника књижевности, његова методичка способност, вештина и воља да ученика-читаоца води до пуног остварења интелектуалних, емоционалних и фантазијских потенцијала које поседује и оптималног развоја његових читалачких компетенција ${ }^{21}$. Тако би поему Мрњавчевићи било занимљиво и методички изазовно укључити у изборну лектиру ученика старијих разреда основне школе управо због интертекстуалности као њеног истакнутог обележја (она омогућава да се, на пример, синтези знања о епском песништву приступи на другачији начин, с полазиштем у модерном тексту који с традицијом успоставља стваралачки и креативан дијалог), али би и средњошколцима могла да буде занимљива јер ће у њој моћи да детектују још више (одразе мита о Пенелопи, везу с наслеђем романтизма и авангарде, с појединим делима светске књижевности...). ${ }^{22}$

\footnotetext{
${ }^{20}$ Нема књижевног критичара који је писао о стваралаштву Попа Ђурђева а да се, оправдано, овом особином његове поетике није бавио. Видети, на пример, радове у зборнику Песничке игре и поиравања Попа Д. Ђурђева (Лазаревац 2019), или нешто раније објављене текстове (RADONIČIĆ 2013), (STOLIĆ 2015) и др.

${ }^{21}$ Видети о овоме: (GROSMAN 2010).

22 У овом раду ограничили смо се на подробније бављење изабраним лирским текстовима Попа Ђурђева. Треба рећи да су и друга његова остварења у методичком смислу подстицајна и захвална за примену интертекстуалног приступа у настави. Тако се, према новом наставном програму из књижевности у 7. разреду основне школе, наставницима
} 
Вратимо се, на крају, неким питањима постављеним у уводном делу овог рада. Одређене одговоре понудила је сама анализа изабраних текстова, нека остају отворена за размишљање. Интертекстуалност и игривост, односно интертекстуалност као вишедимензионална игра јесте важан аспект рецепцијске комуникативности поезије Попа Ђурђева. Она омогућава читање на више нивоа, ,активно, креативно читање у ком се открива текст у односу према другим текстовима, чиме се постиже експлозија значења. Да би досегао задовољавајући ниво рецепције књижевних дела читаоца треба подучити читању, како је наглашавао Ричардс, проширити му интелектуалне хоризонте, залажући се за слободу тумачења текста, који лебди у простору бескрајних могућности, борећи се против уобичајене перцепције и аутоматског читања" (RADULOVIĆ 2011: 8). Ниво читалачког домета младог бића у разоткривању у текст учитаних референци треба, очито, посматрати не као проблем и ограничење већ као изазов.

Не можемо а да се не сложимо са Ђурђевим који, још касних 80тих година 20. века, увиђа како се времена мењају: „Данас се брже расте. Деци књиге окраћају, као панталоне. Стално су им потребне нове. Зато сам покушао да, са што мање инфантилности и што више духа, начиним корак даље од класичне дечје песме” (ĐURĐEV 1988: 71). Млади читаоци желе књигу „уз коју ће се мање осећати децом” (Исто). Остајући, деценијама, доследан овом аутопоетичком ставу, Поп Ђурђев ствара управо такве књиге. Он „несумњиво верује у интелектуалну развијеност савремене деце и њиховог сензибилитета. Он пева на луцидан, духовно провокативан начин за дете у човеку и човека у детету. Он је истовремено и homo ludens и разуздано дете на широким пољима културе' (LJUŠTANOVIĆ 2019: 41).

Та луцидна и интелигентна стваралачка разиграност Попа Ђурђева у којој се, сасвим оригинално, спајају текст и слика (у врло широком опсегу варијанти и значења) производећи дело суштински мултимедијалне природе, у потпуном је сагласју са читалачким склоностима и навикама савремених младих читалаца. ${ }^{23}$ Његова остварења зато представљају

нуди могућност обраде дела Лет лионског Икара (Булићи и увеоии Антоана де СентEгзиперија) које се, поред тога што и само поседује високу естетску вредност и релевантно је за наставно проучавање, показује и као изузетно погодно за повезивање са романом Мали Прини Антоана де Сент-Егзиперија, који представља његов прототекст. Један могући интертекстуални методички приступ, уз изабране фрагменте Ђурђевљеве прозе, видети у: Oдсjaj, читанка за 7. разред основне школе (прир. С. Божић, С. Милосављевић Милић, Ј. Јовановић, М. Бојанић Ћирковић), Београд: Герундијум, 2019, стр. 67-70.

${ }^{23}$ Као финални доказ наводимо најновију песничку збирку Попа Д. Ђурђева Етичко чишћење, бревијар јутутунских похвала лудости (песме и визуелне песме), Нови Сад 2019. 
праве читалачке мамце, просторе укрштања са којих читалачки путеви воде, истовремено, на две важне стране - у књижевну прошлост и књижевну будућност.

\section{Цитирана литература}

BOŽIĆ 2020: BOŽIĆ, Snežana. „Empatijsko-etički model čitanja u nastavi književnosti”. Književna istorija, časopis za nauku o književnosti, Beograd: Institut za književnost i umetnost. (rad prihvaćen za štampu) [orig.] БОЖИЋ, Снежана. „Емпатијско-етички модел читања у настави књижевности”. Кьижевна историја, часопис за науку о књижевности, Београд: Институт за књижевност и уметност, 2020. (рад прихваћен за штампу)

GROSMAN 2010: GROSMAN, Meta. U obranu čitanja: čitatelj i književnost $u$ 21. stoljeću, Zagreb 2010.

JOVANOVIĆ 2017: JOVANOVIĆ, Nemanja. „Adresat u lirskoj poeziji”. Philologia Mediana 9 (2017). Niš: Filozofski fakultet 2017, str. 199-212. [orig.] ЈОВАНОВИЋ, Немања. „Адресат у лирској поезији”. Philologia Mediana 9 (2017). Ниш: Филозофски факултет 2017, стр. 199-212.

KUVAČ LEVAČIĆ 2013: KUVAČ LEVAČIĆ, Kornelija. „Razvoj i vrste čitanja, tipologija čitatelja s obzirom na čitanje 'neknjiževnih' tekstova”. Čitanje za školu $i$ život. IV Simpozij učitelja i nastavnika hrvatskog jezika, zbornik radova. Zagreb: Agencija za odgoj i obrazovanje 2013, str. 13-22.

LJUŠTANOVIĆ 2019: LJUŠTANOVIĆ, Jovan. „O podetinjenju homo ludensa u poeziji za decu Popa D. Đurđeva". Pesničke igre i poigravanja Popa D. Đurđeva, zbornik radova sa naučnog skupa održanog na 30. Međunarodnom festivalu humora za decu u Lazarecvu 19. septembra 2018. godine, Lazarevac 2019, str. 25-43. [orig.] ЉУШТАНОВИЋ, Јован. „О подетињењу hото ludensa у поезији за децу Попа Д. Ђурђева”. Песничке игре и поигравања Попа Д. Бурђева, зборник радова са научног скупа одржаног на 30. Међународном фестивалу хумора за децу у Лазаревцу 19. септембра 2018. године, Лазаревац 2019, стр. 25-43.

LJUŠTANOVIĆ 2018: LJUŠTANOVIĆ, Jovan. „O tipološkim modelima u srpskom pesništvu za decu u 21. veku". Književnost za decu u nauci i nastavi, pos. izd., knj. 21, 2018, str. 61-74. [orig.] ЉУШТАНОВИЋ, Јован. „О типолошким моделима у српском песништву за децу у 21. веку”. Кюижевност за деиу у науции и настави, пос. изд., књ. 21, 2018, стр. 61-74.

MILOSAVLJEVIĆ MILIĆ 2017: MILOSAVLJEVIĆ MILIĆ, Snežana. „Multiplikacija figure čitaoca u književnosti za decu”, izlaganje na 5. naučnom skupu Književnost za decu u nauci i nastavi, Fakultet pedagoških nauka Univerziteta u Kragujevcu, Jagodina, 21. 4. 2017. [orig.] МИЛОСАВљЕВИЋ МИЛИЋ, Снежана. „Мултипликација фигуре читаоца у књижевности за децу”, излагање на 5. научном скупу Кюижевност за 
децу у науц̧и и настави, Факултет педагошких наука Универзитета у Крагујевцу, Јагодина, 21. 4. 2017. година.

OPAČIĆ 2019: OPAČIĆ, Zorana. „'Destruktivno neimarstvo’ Popa D. Đurđeva \& intertekstualno poigravanje u poemi Mrnjavčevići”. Pesničke igre $i$ poigravanja Popa D. Đurđeva, zbornik radova sa naučnog skupa održanog na 30. Međunarodnom festivalu humora za decu u Lazarecvu 19. septembra 2018. godine, Lazarevac 2019, str. 5-23. [orig.] ОПАЧИЋ, Зорана. „'Деструктивно неимарство' Попа Д. Ђурђева \& интертекстуално поигравање у поеми Мрњавчевићи". Песничке игре и поигравања Попа Д. Бурђева, зборник радова са научног скупа одржаног на 30. Међународном фестивалу хумора за децу у Лазаревцу 19. септембра 2018. године, Лазаревац 2019, стр. 5-23.

OPAČIĆ 2018: OPAČIĆ, Zorana. „O živoj vodi - savremena poezija i pripovedna proza za decu i mlade". Srpska književnost danas: zbornik radova sa okruglih stolova 2014-2017. Novi Sad: Srpska akademija nauka i umetnosti, Ogranak, 2018, str. 298-314. [orig.] ОПАЧИЋ, Зорана. „О живој води - савремена поезија и приповедна проза за децу и младе". Српска књижевност данас: зборник радова са округлих столова 2014-2017. Нови Сад: Српска академија наука и уметности, Огранак, 2018, стр. 298-314.

RADONIČIĆ 2013: RADONIČIĆ, Ana. „Intertekstualnost u poeziji Popa D. Đurđeva”. Detinjstvo. Časopis o književnosti za decu. 3/2013, str. 9-21. [orig.] РАДОНИЧИЋ, Ана. „Интертекстуалност у поезији Попа Д. Ђурђева“. Детињство. Часопис о књижевности за дещу, 3/2103, стр. 9-21.

RADOVIĆ 2006: RADOVIĆ, Dušan. „O književnosti za decu kod nas”. Baš svašta: sabrani spisi. Beograd: Zavod za udžbenike i nastavna sredstva, str. 417-419. [orig.] РАДОВИЋ, Душан. „О књижевности за децу код нас”. Баш свашта: сабрани списи. Београд: Завод за уџбенике и наставна средства 2006, стр. 417-419.

RADULOVIĆ 2011: RADULOVIĆ, Olivera. Nove naučne metodologije u nastavi književnosti. Novi Sad 2011. [orig.] РАДУЛОВИЋ, Оливера. Нове научне методологије у настави књижевности. Нови Сад 2011.

RKT 1992: Rečnik književnih termina, ur. Dragiša Živković, Beograd: Nolit, 1992.

ROSANDIĆ 1986: ROSANDIĆ, Dragutin. Metodika književnog odgoja $i$ obrazovanja, Zagreb: Školska knjiga, 1986.

STOLIĆ 2015: STOLIĆ, Danica. „Palimpsest i vizuelizacija kao postupci dekanonizacije u pesništvu Popa D. Đurđeva”. Detinjstvo. Časopis o književnosti za decu. 4/2015, str. 34-40. [orig.] Столић, Даница. „Палимпсест и визуелизација као поступци деканонизације у песништву Попа Д. Ђурђева”. Детињство. Часопис о књижевности за деиу, 4/2015, стр. 34-40.

VUKOVIĆ 1996: VUKOVIĆ, Novo. Uvod u književnost za djecu i omladinu, Podgorica: Unireks 1996. 


\section{Извори}

ĐURĐEV 1988: ĐURĐEV, Pop D. Bludilnik: poetski praktikum za usmerenjake. Beograd 1988. [orig.] Ђурђев, Поп Д. Блудилник: поетски практикум за усмерењаке. Београд 1988.

ĐURĐEV 2016: ĐURĐEV, Pop D. Mrnjavčevići. Čačak 2016. [orig.] Ђypђев, Поп Д. Мрьавчевићи. Чачак 2016.

Snežana V. Božić

\section{INFLUENCE OF INTERTEXTUALITY AND PLAYABILITY ON COMMUNICATIVENESS OF POETRY FOR CHILDREN AND YOUTH BY POP D. ĐURĐEV}

This paper is examining the influence of intertextuality, as an important attribute of Pop D. Đurđev's creative opus, on the level of communicativeness in his poetry, with a special focus on the primarily intended audience - children and youth. This paper addresses two main questions: First, is intertextuality introducing the aspect of playability in the text? Second, which levels of the "playable" text are actually reached during the act of reception by the childreader? In order to answer these two key questions as well as many additional ones, two literature creations by Pop Đurđev were analyzed: anthology Bludilnik (1988) and poem Mrnjavčevići (2016).

Keywords: intertextuality, playability, children's poetry, child-reader, reading competencies 